\title{
Effect of supplementation with fish oil or microalgae on fatty acid composition of milk from cows managed in confinement or pasture systems
}

\author{
P. Vahmani, ${ }^{*}$ A. H. Fredeen, $\dagger^{1}$ and K. E. Glover $¥$ \\ *Department of Biology, Dalhousie University, Halifax, Nova Scotia B3H 4J1, Canada \\ †Department of Plant and Animal Sciences, Dalhousie University, Truro, Nova Scotia B2N 5E3, Canada \\ $\ddagger$ Azar Agriculture, Truro, Nova Scotia B2N 5Z3, Canada
}

\section{ABSTRACT}

The objective of this study was to examine the interaction between lipid supplement (LS) and management system (MS) on fatty acid (FA) composition of milk that could affect its healthfulness as a human food. Forty-eight prepartal Holstein cows were blocked by parity and predicted calving date and deployed across pasture (PAS; $\mathrm{n}=23$ ) or confinement (CONF; $\mathrm{n}=$ 25) systems. Cows within each system were assigned randomly to a control (no marine oil supplement) or to 1 of 2 isolipidic $(200 \mathrm{~g} / \mathrm{d})$ marine oil supplements: fish oil (FO) or microalgae (MA) for $125 \pm 5 \mathrm{~d}$ starting 30 d precalving. The experiment was conducted as a splitplot design, with MS being the whole-plot treatment and LS as the subplot treatment. Cows were housed in a tie-stall barn from -30 until $28 \pm 10 \mathrm{~d}$ in milk (DIM) and were fed total mixed rations with similar formulations. The PAS group was then adapted to pasture and rotationally grazed on a perennial sward until the end of the experiment (95 \pm 5 DIM). Milk samples were collected at 60 and 90 DIM for major components and FA analyses. Milk yield (kg/d) was lower in PAS (34.0) compared with CONF (40.1) cows. Milk fat percentage was reduced with MA compared with FO (3.00 vs. 3.40) and the control (3.56) cows. However, milk fat yield $(\mathrm{kg} / \mathrm{d})$ was not affected by lipid supplements. Compared with CONF, PAS cows produced milk fat with a lower content of 12:0 (-38\%), 14:0 (-28\%), and 16:0 (-17\%), and more cis-9 18:1 (+32\%), 18:3 n-3 (+30\%), conjugated linoleic acid (CLA; +70\%) and trans 18:1 (+34\%). Both supplements, regardless of MS, reduced similarly the milk fat content of 16:0 $(-12 \%)$ and increased CLA $(+28 \%)$ and n-3 long-chain polyunsaturated FA (n-3 LC-PUFA; +150\%). Milk fat content of trans 18:1 (trans-6 to trans-16) was increased with FO or MA, although the effect was greater with MA $(+81 \%)$ than with FO $(+42 \%)$. The interaction

Received April 10, 2013.

Accepted June 23, 2013.

${ }^{1}$ Corresponding author: alan.fredeen@dal.ca between MS and LS was significant only for trans-11 18:1 (vaccenic acid, VA) and cis-9, trans-11 CLA (rumenic acid). In contrast to CONF, feeding FO or MA to PAS cows did not increase milk fat content of VA and rumenic acid. We concluded that compared with CONF, milk from PAS cows had a more healthful FA composition. Feeding either FO or MA improved n-3 long-chain polyunsaturated $\mathrm{FA}$ and reduced levels of 16:0 in milk fat, regardless of MS, but concurrently increased the trans 18:1 isomers other than VA, at the expense of VA, particularly in grazing cows.

Key words: dairy cow, grazing, total mixed ration, marine oil

\section{INTRODUCTION}

Milk in temperate North America is increasingly produced using year-round confinement systems and to a lesser and shrinking extent, pasture systems which use grazing for about half the year. The diets of cows are substantially different between these systems. Grazing cows consume fresh forage with less grain fed, typically twice daily at milking, whereas confined cows are fed conserved forages, corn silage, and grains in a TMR. Although higher milk production is achieved by confining cows, the higher profitability (Rust et al., 1995) and lower environmental impact (Arsenault et al., 2009) of pasture systems results from reduced use of purchased inputs (e.g., grain) and lower use of farm infrastructure and machinery. As well as having environmental and cost benefits, milk from grazing cows has a more healthful FA profile than that of confined cows (Vahmani et al., 2013). Previous studies (Dewhurst et al., 2006; Chilliard et al., 2007; Kalač and Samková, 2010) showed that compared with cows fed conserved forages in confinement, grazing cows produce milk with a lower fat content of SFA, particularly 12:0, 14:0, and 16:0, and higher content of beneficial unsaturated FA (UFA), including cis-9 18:1 (oleic acid, OA); trans-11 18:1 (vaccenic acid; VA); conjugated linoleic acid (CLA), particularly cis-9, trans-11 CLA (rumenic acid; RA); and 18:3 n-3 ( $\alpha$-linolenic acid; ALA). 
Milk fat is naturally almost devoid of n-3 long-chain PUFA (n-3 LC-PUFA), specifically eicosapentaenoic acid (EPA; 20:5n-3) and docosahexaenoic acid (DHA; 22:6n-3). Fish oil (FO) has been the most common source of n-3 LC-PUFA used in dairy rations to improve the milk fat content of these FA. Microalgae (MA), at the bottom of marine food chains, are the primary producers of n-3 LC-PUFA. Recently, biofermentor technology has been used for production of heterotrophic microalgal biomass (e.g., Schizochytrium spp.), which is mainly used as a source of DHA for aquaculture (Sijtsma and de Swaaf, 2004). A few recent studies (Boeckaert, et al., 2008; AbuGhazaleh et al., 2009; Glover et al., 2012; Stamey et al., 2012) have successfully used MA as a ration supplement for the enrichment of milk with DHA.

The majority of consumed PUFA is biohydrogenated in the rumen and not incorporated into milk intact. The transfer efficiencies of EPA and DHA from diet into milk have been estimated to be 2.6 and $4.1 \%$, respectively (Chilliard et al., 2001). However, the transfer efficiencies of EPA and DHA were increased several fold when the source was protected from ruminal biohydrogenation (RBH; Franklin et al., 1999; Kitessa et al., 2004).

Although MA and FO are not significant sources of C18 UFA (precursors for ruminal production of VA and RA), they are more effective than plant oils in increasing milk concentrations of VA and RA (Chilliard et al., 2007). The n-3 LC-PUFA may inhibit the final step of RBH where VA is converted to 18:0 (AbuGhazaleh and Jenkins, 2004). The enhanced ruminal outflow of VA increases the milk fat content of VA as well as that of RA, because of mammary conversion of VA to RA (Shingfield et al., 2010).

Higher intake of ALA by cows grazing fresh forage in pasture systems and specific ruminal conditions in grazing cows (e.g., low ruminal $\mathrm{pH}$ and high ruminal passage rate) play roles in causing differences in milk FA composition compared with that of confined cows (Schroeder et al., 2004; Dewhurst et al., 2006). Depressed ruminal $\mathrm{pH}$ combined with high ruminal passage rate in grazing cows can reduce the completeness of $\mathrm{RBH}$ and potentially increase the transfer rate of dietary UFA and their RBH intermediates to milk compared with cows fed in confinement. There is increasing focus on the healthfulness of food and knowledge regarding the health effects of the types of fats in our diets. The potential for the dairy farm management system to affect the healthfulness of milk fat requires further study. The objective of this research was to determine the interaction of dairy farm management system (MS; pasture vs. confinement) and source of marine lipid supplement (LS; FO vs. MA) on milk FA composition. We hypothesized that response of milk FA composition to LS would be affected by MS. We further hypothesized that the different proportions of EPA and DHA in the n-3 LC-PUFA of supplemented FO compared with MA would influence differently the milk FA composition, including content of CLA and trans 18:1 isomers.

\section{MATERIALS AND METHODS}

\section{Animals, Experimental Design, and Treatments}

All procedures and protocols involving animals in this study were approved by the Animal Care and Use Committee of the Dalhousie Agricultural Campus (Truro, Nova Scotia, Canada). Forty-eight prepartal Holstein cows were blocked by parity and predicted calving date and deployed randomly within block to pasture $(\mathrm{n}=23)$ or confinement $(\mathrm{n}=25)$ systems. Cows within each system were assigned randomly to a control (no marine oil supplement), FO (EPAX 5500; Pronova Biocare, Ålesund, Norway), or MA (Algamac-3050; Aquafauna Bio-Marine Inc., Hawthorne, CA) group. Both FO and MA were encapsulated with $\begin{array}{llll}\text { a saturated lipid containing } & 75 \% & 18: 0 \text { and } 25 \% & 16: 0\end{array}$ to provide protection against RBH (Animal Nutrition Laboratory, Faculty of Agriculture, Dalhousie University, Truro, Nova Scotia, Canada), and were stored at $-20^{\circ} \mathrm{C}$ until feeding, which began $30 \mathrm{~d}$ before calving and continued until $95 \pm 5$ DIM. Supplements provided similar amounts of total lipid $(200 \mathrm{~g} / \mathrm{d})$ and LC-PUFA ( $\sim 65 \mathrm{~g} / \mathrm{d}$; Table 1$)$, but contained different proportions of EPA and DHA. The predominant LC-PUFA in FO was EPA, whereas DHA was the major LC-PUFA in MA (Table 1). Lipid supplements were mixed with 1 $\mathrm{kg}$ of TMR (as fed; Table 2) and were hand-fed to both pasture and confinement groups. This was the only TMR offered to grazing cows.

Pasture and confinement groups were housed in the same tie-stall facility and fed 4 different TMR: (1) dry cow ( -32 to -22 DIM), (2) close up (-21 DIM to calving), (3) postcalving (calving to 9 DIM), or (4) lactation (10 DIM to either $28 \pm 10$ or $95 \pm 5$ DIM for pasture and confinement, respectively). All rations were formulated using the CPM-Dairy cattle ration analyzer (Cornell-Penn-Miner version 3.0.8; Miner Institute, Chazy, NY). Pasture group was adapted to pasture at $28 \pm 10$ DIM by increasing the grazing time from 12 $\mathrm{h} / \mathrm{d}$ for $1 \mathrm{wk}$ to $21 \mathrm{~h} / \mathrm{d}$, which continued until the end of experiment (95 \pm 5 DIM). Cows rotationally grazed a perennial sward consisting of bluegrass (Poa pratensis; $17-20 \%$ ), white clover (Trifolium repens; $14-18 \%$ ), timothy (Phleum pratense; 8-12\%), and other pasture species and forbs (28-30\%). The period of stay was 
Table 1. Fatty acid composition [ $\mathrm{g}$ of FA/100 $\mathrm{g}$ of total FA (values in parentheses represent $\mathrm{g} / \mathrm{d}$ of the FA)] of feeds and lipid supplements

\begin{tabular}{|c|c|c|c|c|c|}
\hline \multirow[b]{2}{*}{ FA } & \multicolumn{2}{|c|}{ Feed } & \multirow[b]{2}{*}{$\mathrm{TMR}^{1}$} & \multicolumn{2}{|c|}{ Lipid supplement } \\
\hline & Concentrate & Pasture & & $\mathrm{MA}^{2}$ & $\mathrm{FO}^{3}$ \\
\hline 14:0 & 0.15 & 0.43 & 0.48 & $5.31(17.4)$ & $0.40(8.0)$ \\
\hline 16:0 & 11.95 & 10.93 & 14.53 & $25.02(51.1)$ & $12.67(25.3)$ \\
\hline 18:0 & 2.09 & 1.21 & 1.98 & $32.48(75.1)$ & $38.68(77.4)$ \\
\hline cis-9 18:1 & 21.69 & 2.30 & 13.46 & $0.06(0.1)$ & $4.10(8.2)$ \\
\hline cis-9, cis-12 18:2 & 51.69 & 13.23 & 35.46 & $\mathrm{ND}^{4}$ & $0.57(1.13)$ \\
\hline cis-9, cis-12, cis-15 18:3 & 2.24 & 48.14 & 13.36 & ND & $1.29(2.58)$ \\
\hline $20: 5 n-3$ & ND & ND & ND & $1.61(3.0)$ & $15.85(31.7)$ \\
\hline $22: 5 n-3$ & ND & ND & ND & ND & $2.01(4.0)$ \\
\hline $22: 5 n-6$ & ND & ND & ND & $9.54(17.7)$ & ND \\
\hline $22: 6 \mathrm{n}-3$ & ND & ND & ND & $24.23(45.0)$ & $12.33(24.7)$ \\
\hline $\mathrm{SFA}^{5}$ & 15.62 & 15.81 & 21.09 & $62.80(143.6)$ & $51.74(110.7)$ \\
\hline MUFA & 24.56 & 7.76 & 19.44 & $0.06(0.11)$ & $7.35(14.7)$ \\
\hline PUFA & 56.77 & 71.35 & 56.05 & $35.51(66.9)$ & $36.33(72.0)$ \\
\hline C20-22 PUFA & 0.13 & 0.77 & 0.36 & $35.51(65.9)$ & $32.62(65.3)$ \\
\hline C20-22n-3 PUFA & 0.04 & 0.28 & 0.11 & $25.84(48.0)$ & $30.18(60.3)$ \\
\hline
\end{tabular}

${ }^{1}$ Total mixed ration was fed from 10 to $95 \pm 5$ DIM to the confinement group only.

${ }^{2}$ Rumen-protected microalgae.

${ }^{3}$ Rumen-protected fish oil.

${ }^{4}$ Values $<0.05 \%$ were considered not detectable (ND).

${ }^{5}$ Total SFA.

Table 2. Ingredient and nutritive composition of feeds

\begin{tabular}{|c|c|c|c|}
\hline Item & $\mathrm{TMR}^{1}$ & Concentrate & Pasture \\
\hline \multicolumn{4}{|l|}{ Ingredient, $\%$ of DM } \\
\hline Corn silage & 22.46 & & \\
\hline Grass silage & 28.61 & & \\
\hline Second-cut hay & 6.10 & & \\
\hline Barley & 10.40 & 24.30 & \\
\hline Corn distillers grains (dried) & 4.30 & 10.05 & \\
\hline Energy Booster ${ }^{2}$ & 0.95 & 2.21 & \\
\hline Soybean meal ( $48 \% \mathrm{CP})$ & 10.64 & 24.85 & \\
\hline Corn grain & 10.40 & 24.30 & \\
\hline Top Soy ${ }^{3}$ & 3.55 & 8.28 & \\
\hline Limestone & 0.95 & 2.21 & \\
\hline Dicalcium phosphate & 0.24 & 0.55 & \\
\hline Sodium bicarbonate & 0.47 & 1.10 & \\
\hline Magnesium oxide & 0.05 & 0.11 & \\
\hline Yeast culture $^{4}$ (dehydrated) & 0.24 & 0.55 & \\
\hline Iodized salt & 0.38 & 0.88 & \\
\hline Vitamin and mineral mix ${ }^{5}$ & 0.26 & 0.61 & \\
\hline \multicolumn{4}{|l|}{ Nutrient content } \\
\hline $\mathrm{DM}, \%$ & 53.22 & 90.65 & 24.37 \\
\hline $\mathrm{CP}, \%$ of $\mathrm{DM}$ & 17.89 & 25.68 & 16.59 \\
\hline $\mathrm{NE}_{\mathrm{L}}, \mathrm{Mcal} / \mathrm{kg}$ & 1.76 & 2.06 & 1.53 \\
\hline $\mathrm{NDF}, \%$ of DM & 31.95 & 13.93 & 41.27 \\
\hline $\mathrm{ADF}, \%$ of $\mathrm{DM}$ & 18.53 & 5.93 & 28.63 \\
\hline Ash, $\%$ of DM & 8.02 & 9.67 & 9.14 \\
\hline Ether extract, $\%$ of DM & 4.64 & 6.05 & 3.94 \\
\hline
\end{tabular}

${ }^{1}$ Total mixed ration was fed from 10 to $95 \pm 5$ DIM to the confinement group only.

${ }^{2}$ Energy Booster contained primarily 16:0 and 18:0 (Milk Specialties Co., Dundee, IL).

${ }^{3}$ Shur-Gain Top Soy (bypass soybean meal; Shur-Gain, Guelph, ON, Canada).

${ }^{4}$ Saccahromyces cerevisiae culture (Diamond V Mills Inc., Cedar Rapids, IA).

${ }^{5}$ Contained $0.48 \% \mathrm{Cu}, 0.73 \% \mathrm{Zn}, 0.1 \% \mathrm{Co}, 105 \mathrm{mg}$ of $\mathrm{Se} / \mathrm{kg}, 150,000 \mathrm{IU}$ of vitamin $\mathrm{A} / \mathrm{kg}, 1,600,000 \mathrm{IU}$ of vitamin $\mathrm{D} / \mathrm{kg}$, and $13,500 \mathrm{IU}$ of vitamin $\mathrm{E} / \mathrm{kg}$. 
based on target sward heights, which were 20 to 30 and 5 to $10 \mathrm{~cm}$ for pre- and postgrazing, respectively. The stocking rate varied from 23 to 30 cows/ha.

Cows were milked daily at 0600 and $1600 \mathrm{~h}$ and individual milk production was recorded at each milking. Confined cows were fed ad libitum twice daily at 0700 and $1500 \mathrm{~h}$, allowing approximately 10\% orts (as-fed basis). The amount of feed offered and refused was recorded daily for the calculation of DMI. Concentrate was fed to the pasture group at the rate of $25 \%$ (wt/wt, as fed) of milk yield, to a maximum of $8.0 \mathrm{~kg}$ daily. All grazing cows received the maximal level. This concentrate was the same as that used in the lactation TMR for confined cows (Table 2) and was fed in 2 equal portions at morning and afternoon milkings. The FA and chemical composition of feeds are presented in Tables 1 and 2, respectively. Water was provided free choice.

\section{Measurements, Sampling, and Analyses}

Milk yield and feed intake were recorded daily. Milk samples were collected during 4 consecutive milkings at 59 to 60 and 89 to 90 DIM. Samples were composited by day proportional to milk yield at each milking and then split into 2 aliquots. One aliquot was analyzed for fat, protein, and lactose by infrared spectrophotometry (Fossomatic 4000 MilkoScan analyzer; Foss North America, Brampton, Ontario, Canada). The second aliquot was flushed with nitrogen gas and then stored at $-80^{\circ} \mathrm{C}$ for FA analysis. Body weight and BCS (Wildman et al., 1982) were recorded on 60 and 90 DIM, as well as -31 DIM, which were used as covariates. Samples of pasture, TMR, and concentrate were collected weekly and stored at $-20^{\circ} \mathrm{C}$. Frozen samples were later composited by month and analyzed as described by Glover et al. (2012).

Lipids were extracted from milk samples using chloroform/methanol/water (2:1:0.8, by vol) based on a modified Folch et al. (1957) procedure as described by Budge et al. (2006). Extracted lipids were derivatized using $0.5 \mathrm{~N} \mathrm{NaOCH}_{3} /$ methanol $\left(15 \mathrm{~min}\right.$ at $50^{\circ} \mathrm{C}$; Supelco Inc., Bellefonte, PA; Cruz-Hernandez et al., 2006). The resulting FA methyl esters (FAME) were dissolved to $0.5 \mathrm{mg} / \mathrm{mL}$ in hexane for analysis using 2 GC methods (modification of Kramer et al., 2008). The temperature program for the first method (GC method A) was $45^{\circ} \mathrm{C}$ for $4 \mathrm{~min}$, and then the temperature was increased to $175^{\circ} \mathrm{C}$ at a rate of $13^{\circ} \mathrm{C} / \mathrm{min}$, held for 27 min, and then increased to $215^{\circ} \mathrm{C}$ at a rate of $4^{\circ} \mathrm{C} / \mathrm{min}$ and held for $35 \mathrm{~min}$. Gas chromatography method A had a column flow rate of $0.5 \mathrm{~mL} / \mathrm{min}$ and used a split injection with a ratio of $3: 1$. The temperature program for GC method B used a plateau of $150^{\circ} \mathrm{C}$ held for 47 min instead of $175^{\circ} \mathrm{C}$ for $27 \mathrm{~min}$, but otherwise was the same as GC method A. The column flow rate for GC method $\mathrm{B}$ was $0.7 \mathrm{~mL} / \mathrm{min}$ and splitless injection was used. The gas chromatograph (Varian 3800 GC; Varian Inc., Walnut Creek, CA) was equipped with a Varian 8100 autosampler, a flame ionization detector, and a Supelco SP-2560 fused silica capillary column (100 m $\times 0.25$-mm i.d. $\times 0.2-\mu \mathrm{m}$ film thickness; Supelco Inc.). The injector and the detector were maintained at 250 and $270^{\circ} \mathrm{C}$, respectively. The gas flow to the flame ionization detector was set as follows: air: $300 \mathrm{~mL} / \mathrm{min}$, hydrogen: $30 \mathrm{~mL} / \mathrm{min}$, and helium make-up gas: 29 $\mathrm{mL} / \mathrm{min}$, with a carrier gas flow of either 0.5 or 0.7 $\mathrm{mL}$ of hydrogen/min, depending on the GC method. Reference standards 463, 481B, 21:0, and CLA isomer mixture UC-59M were purchased from Nu-Chek Prep. Inc. (Elysian, MN) and used for the identification of FAME. Any CLA or trans 18:1 isomers not in the above standards was identified by comparison with previously reported GC analysis of milk FAME (Cruz-Hernandez et al., 2006; Kramer et al., 2008).

\section{Calculations}

The intake of pasture forage in grazing cows was calculated using the difference between $\mathrm{NE}_{\mathrm{L}}$ output (lactation + maintenance) and concentrate $\mathrm{NE}_{\mathrm{L}}$ intake, as well as the $\mathrm{NE}_{\mathrm{L}}$ content of pasture (Cosgrove and Cooper, 2007). Total DMI of grazing cows was the sum of concentrate DMI and estimated pasture DMI.

Transfer efficiencies of EPA and DHA from diet to milk were calculated for individual cows fed LS as [(FA yield $(\mathrm{g} / \mathrm{d})$ in milk) - (mean of FA yield $(\mathrm{g} / \mathrm{d})$ of control cows)]/[amount of FA (g/d) provided by the LS]. Milk FA yields were calculated according to Glasser et al. (2007).

\section{Statistical Analysis}

Data were analyzed using PROC MIXED of SAS (version 9.2; SAS Institute Inc., Cary, NC) according to a split-plot model. Management system and LS were considered as fixed factors, and block was treated as a random factor. To limit the confounding effect of seasonal changes in pasture forage composition and number of days on pasture, only milk FA data from DIM 90 was used for statistical analysis. For the remaining variables, DIM was included in the model as a repeated factor. A covariate was added to the model for the analyses of BW and BCS data, for which pretrial measurements ( -31 DIM) were available. Least squares means were separated using the PDIFF statement in SAS. Differences were declared significant at $P \leq 0.05$ and tendencies declared at $0.05>P \leq 0.10$. 


\section{RESULTS}

\section{Animal Performance}

No interactions between MS and LS were observed regarding animal performance variables (Table 3). Dry matter intake, and yields of uncorrected milk, 3.5\% FCM, fat, protein, and lactose were lower $(P \leq 0.05)$ for pasture compared with confinement cows. Body condition score tended $(P=0.10)$ to be lower in grazing compared with confined cows. The main effect of LS was significant only for milk fat percentage, which was reduced $(-16 \% ; P<0.01)$ with MA compared with either FO or the control. Supplementation with FO did not change milk fat percentage compared with the control.

\section{Milk FA Composition}

No significant MS $\times$ LS were observed for any of the selected FA or FA categories presented in Table 4 , but the main effects of MS and LS were significant $(P \leq 0.05)$ for most FA. Milk concentrations of 12:0, $14: 0$, and $16: 0$ were reduced $(P \leq 0.01)$ by 38,28 , and $17 \%$ when cows were grazing compared with those in confinement. The concentrations of 18:0 $(+22 \%)$, OA $(+32 \%)$, and ALA $(+30 \%)$ were greater $(P<0.05)$ in milk from cows on pasture compared with those in confinement. Supplementation with MA significantly reduced $(P<0.05)$ milk fat concentrations of 12:0 and 14:0 by 22 and $15 \%$, respectively, compared with either FO or the control. Supplementation with FO did not change the concentrations of these FA compared with the control. Both LS reduced $(P<0.01)$ the concentration of $16: 0$ by $12 \%$ compared with the control.

The milk fat concentrations of n-3 LC-PUFA paralleled the concentrations of these FA in marine oil supplements fed (Tables 1 and 4). Cows fed FO had higher $(P<0.01)$ milk fat concentrations of EPA $(+100 \%)$ and $22: 5 \mathrm{n}-3(+86 \%)$ compared with those fed the control or MA. Both supplements increased $(P<$ 0.01) the milk fat concentration of DHA compared with the control and the effect was greater $(P<0.01)$ with MA $(+900 \%)$ than with FO $(+600 \%)$. Supplementation with MA also increased $(P<0.01)$ the concentration of 22:5n-6, whereas this FA was not detectable in milk from cows fed the control or FO (Table 4). The calculated transfer efficiency of EPA from FO into milk was $3.46 \pm 0.98$ and $2.97 \pm 0.88 \%$ in grazing and confined cows, respectively. The transfer efficiency of supplemental DHA into milk was similar between FO and MA, and between grazing and confined cows with the overall mean of $5.32 \pm 1.05 \%$.

Grazing reduced $(P=0.01)$ milk fat content of SFA by $14 \%$ compared with confinement (Table 4$)$. Concurrently, the pasture group had higher $(P<0.05)$ milk fat contents of cis MUFA $(+23 \%)$, trans MUFA $(+35 \%)$, and CLA $(+70 \%)$ compared with the confinement group. The higher milk fat content of cis MUFA and trans MUFA in the pasture group was mainly due to the substantial increase in the content of OA $(+32 \%)$ and trans 18:1 (+34\%). Grazing cows tended $(P=$ 0.09 ) to have a higher milk fat content of n-3 PUFA, which was mainly due to the higher content of ALA

Table 3. Effect of management system and lipid supplement on milk yield, milk composition, BW, BCS, and DMI ${ }^{1}$

\begin{tabular}{|c|c|c|c|c|c|c|c|c|c|c|}
\hline \multirow[b]{2}{*}{ Item } & \multicolumn{3}{|c|}{ Management system ${ }^{2}$} & \multicolumn{4}{|c|}{ Lipid supplement ${ }^{3}$} & \multicolumn{3}{|c|}{ Effect, ${ }^{4} P$-value } \\
\hline & PAS & $\mathrm{CON}$ & SEM & $\mathrm{CO}$ & $\mathrm{FO}$ & MA & SEM & MS & LS & $\mathrm{MS} \times \mathrm{LS}$ \\
\hline Milk yield, kg/d & 34.02 & 40.09 & 4.14 & 36.48 & 35.57 & 39.11 & 4.21 & 0.05 & 0.15 & 0.77 \\
\hline $3.5 \% \mathrm{FCM}, \mathrm{kg} / \mathrm{d}$ & 32.76 & 40.45 & 3.80 & 37.64 & 35.09 & 37.08 & 3.89 & 0.04 & 0.40 & 0.95 \\
\hline Fat, $\%$ & 3.18 & 3.46 & 0.09 & $3.56^{\mathrm{a}}$ & $3.40^{\mathrm{a}}$ & $3.00^{\mathrm{b}}$ & 0.11 & 0.16 & $<0.01$ & 0.49 \\
\hline Fat, kg/d & 1.10 & 1.41 & 0.12 & 1.34 & 1.21 & 1.21 & 0.13 & 0.05 & 0.22 & 0.98 \\
\hline Protein,* \% & 2.81 & 3.04 & 0.05 & 2.96 & 2.97 & 2.85 & 0.05 & 0.08 & 0.09 & 0.07 \\
\hline Protein, kg/d & 0.95 & 1.22 & 0.12 & 1.09 & 1.06 & 1.11 & 0.12 & 0.02 & 0.67 & 0.75 \\
\hline Lactose, $\%$ & 4.57 & 4.62 & 0.04 & 4.57 & 4.64 & 4.58 & 0.05 & 0.42 & 0.42 & 0.36 \\
\hline Lactose, $\mathrm{kg} / \mathrm{d}$ & 1.56 & 1.86 & 0.19 & 1.67 & 1.66 & 1.80 & 0.19 & 0.05 & 0.24 & 0.89 \\
\hline $\mathrm{BW}, \mathrm{kg}$ & 610 & 665 & 33.2 & 630 & 634 & 648 & 29.7 & 0.27 & 0.59 & 0.29 \\
\hline $\mathrm{BCS}^{5}$ & 2.51 & 2.83 & 0.07 & 2.63 & 2.70 & 2.68 & 0.08 & 0.10 & 0.75 & 0.98 \\
\hline $\mathrm{DMI},{ }^{6 *} \mathrm{~kg} / \mathrm{d}$ & 19.26 & 23.41 & 2.02 & 21.95 & 20.71 & 21.34 & 2.05 & 0.02 & 0.23 & 0.94 \\
\hline
\end{tabular}

\footnotetext{
${ }^{\mathrm{a}, \mathrm{b}}$ Values within lipid supplement and in the same row not sharing a common superscript are significantly different $(P \leq 0.05)$.

${ }^{1}$ Least squares means are from combined 60 and 90 DIM.

${ }^{2} \mathrm{PAS}=$ pasture system $; \mathrm{CON}=$ confinement system.

${ }^{3}$ Supplementation with rumen-protected fish oil (FO), rumen-protected microalgae (MA), or control (CO; no marine oil supplement).

${ }^{4}$ Effects of management system (MS), lipid supplement (LS) and their interaction (MS $\times$ LS).

${ }^{5}$ Body condition score: $1=$ thin to $5=$ fat (Wildman et al., 1982).

${ }^{6}$ Dry matter intake of grazing cows based on net energy balance (Cosgrove and Cooper, 2007).

*Significant DIM $\times$ MS $(P \leq 0.05)$.
} 
Table 4. Effect of management system and lipid supplement on milk FA composition (g/100 g of total FA) ${ }^{1}$

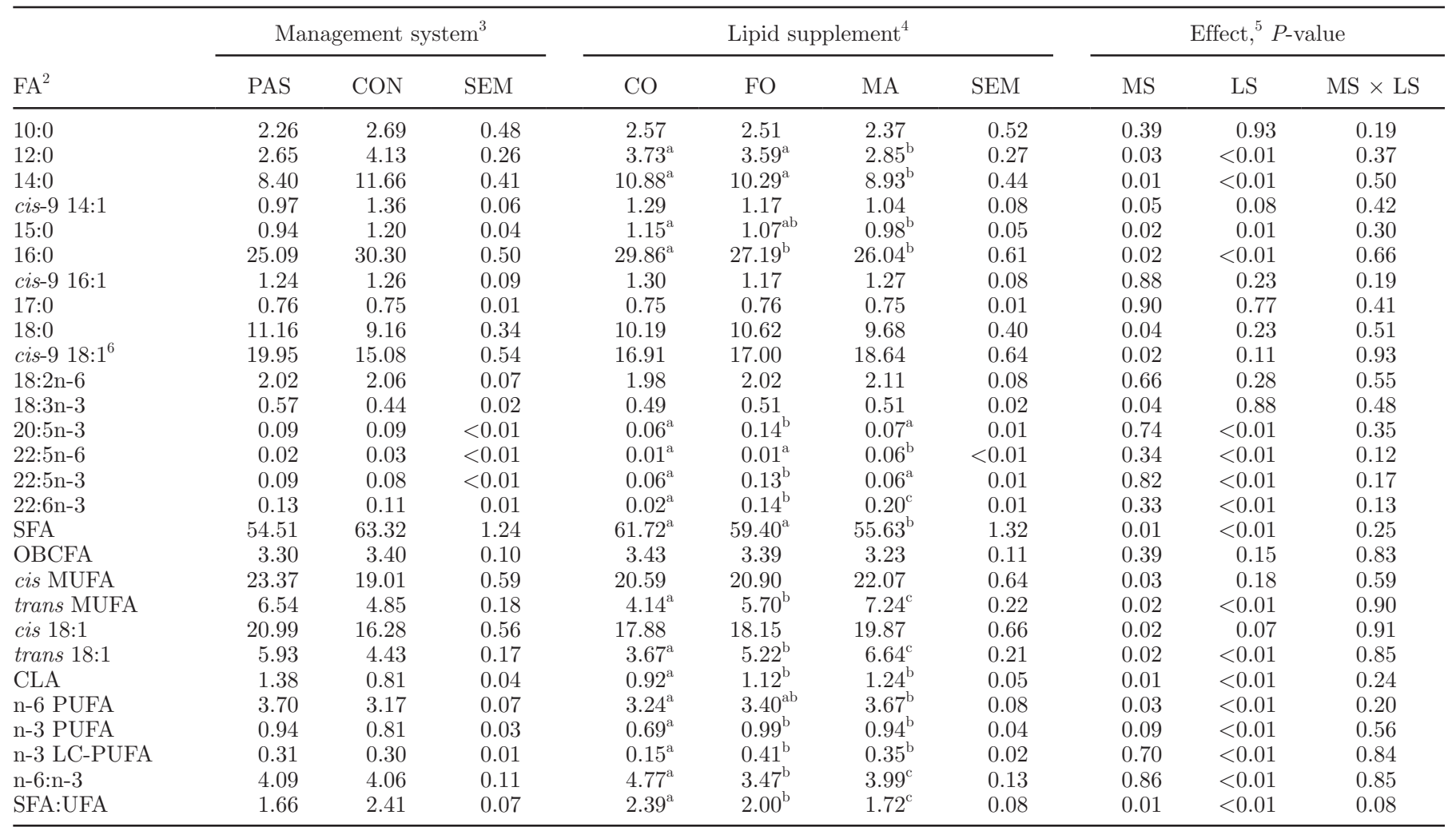

${ }^{\mathrm{a}-\mathrm{C}}$ Values within lipid supplement and in the same row not sharing a common superscript are significantly different $(P \leq 0.05)$.

${ }^{1}$ Least squares means from 90 DIM.

${ }^{2} \mathrm{SFA}=$ total SFA; OBCFA = total odd- and branched-chain FA; CLA = total conjugated linoleic acid isomers; $\mathrm{n}-3$ LC-PUFA = n-3 long-chain (C20-22) PUFA; SFA:UFA = saturated to unsaturated FA ratio.

${ }^{3} \mathrm{PAS}=$ pasture system; CON $=$ confinement system.

${ }^{4}$ Supplementation with rumen-protected fish oil (FO), rumen-protected microalgae (MA), or control (CO; no marine oil supplement).

${ }^{5}$ Effects of management system (MS), lipid supplement (LS), and their interaction (MS $\times$ LS).

${ }^{6}$ Co-elutes with cis-10 18:1.

in pasture (Table 1). The milk SFA:UFA ratio was lower $(P=0.01)$ for cows on pasture compared with those in confinement, despite having higher content of 18:0. Supplementation with MA reduced $(P<0.05)$ the content of SFA $(-9.0 \%)$ compared with FO or the control. However, FO did not change the concentration of SFA. The concentration of trans 18:1 was increased $(P<0.01)$ with either FO or MA, although the effect was greater $(P<0.01)$ with MA $(+81 \%)$ than with FO $(+42 \%)$. Both LS increased $(P \leq 0.01)$ milk fat content of n-3 PUFA, CLA, and n-3 LC-PUFA compared with the control by 40,28 , and $150 \%$, respectively. Supplementation with FO or MA reduced $(P<0.01)$ the n6:n-3 and SFA:UFA ratios (Table 4).

Milk fat concentrations of trans 18:1 and CLA isomers are presented in Table 5 . The main effect of MS was not significant for most of the trans 18:1 isomers, except VA and trans-16 18:1, which were higher for the pasture group. However, the main effect of LS was significant $(P<0.01)$ for almost all isomers, except trans -4 and trans -5 18:1 $(P>0.10)$. Supplementation with FO or MA increased $(P<0.01)$ the milk fat content of trans-6 to trans-16 18:1 compared with the control and the effect was always greater $(P<0.01)$ with MA than with FO. The range of increase compared with the control was 37 to $80 \%$ and 67 to $115 \%$ for FO and MA, respectively. We observed a significant MS $\times$ LS interaction $(P=0.03)$ for VA (Table 5$)$. As shown in Figure 1, supplementation of grazing cows with FO or MA did not significantly increase the milk concentration of VA, whereas both supplements increased $(P$ $<0.05)$ the concentration of VA in confined cows and the effect was greater $(P<0.05)$ with MA $(+45 \%)$ than with $\mathrm{FO}(+22 \%)$.

The milk fat of grazing cows had greater $(P<0.01)$ concentrations of RA and trans-11,cis-13 CLA compared with those of cows in confinement (Table 5). Both LS increased $(P<0.01)$ the milk content of trans-9, cis-11 


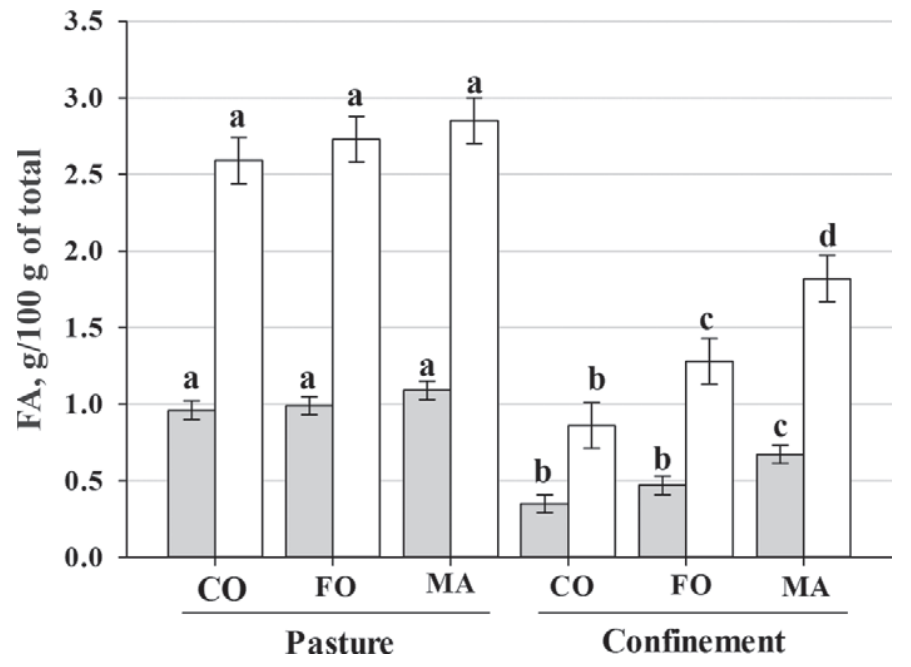

Figure 1. Least squares means showing management system $\times$ lipid supplement interactions for milk fat content of trans-11 18:1 (vaccenic acid; white bars) and cis-9,trans-11 conjugated linoleic acid (rumenic acid; gray bars) in Holstein cows on pasture or in confinement receiving no marine oil supplement (control, CO), rumen-protected fish oil (FO), or rumen-protected microalgae (MA). Least squares means within FA type with different letters $(\mathrm{a}-\mathrm{d})$ are significantly different $(P \leq 0.05)$. Error bars represent $2 \times$ SEM.
CLA, cis-11,trans-13 CLA, and trans,trans CLA isomers. A significant MS $\times$ LS interaction was observed $(P=0.04)$ for RA, with a similar response trend to VA (Figure 1). The concentrations of trans-10, cis-12 and trans-11,trans-13 CLA were not affected by dietary treatments (Table 5).

Table 6 presents the trans-18:1 isomer distribution as a percentage of total trans-18:1 for all treatment combinations. As expected, VA was the major milk trans 18:1 isomer across all dietary treatments. The MS $\times$ LS interaction was significant $(P<0.05)$ for the relative concentration of trans-11 (VA) to trans-16 18:1. The relative concentration of VA for the pasture group was reduced $(P<0.01)$ by feeding $\mathrm{FO}$ or $\mathrm{MA}$, which was accompanied by an increase in the relative concentrations of other trans-18:1 isomers with the double bonds on carbons 12 to 16 (Table 6). In contrast, the relative concentration of VA was not affected when FO or MA were fed to the confinement group. The relative concentrations of trans-9 and trans-10 18:1 were not affected by MS or LS. However, the relative concentration of trans-6 to trans-8 18:1 was reduced $(P<0.01)$ with either FO or MA. Relative concentrations of trans- 4 and trans-5 18:1 tended $(P \leq 0.08)$ to be higher in

Table 5. Effect of management system and lipid supplement on trans 18:1 and conjugated 18:2 isomers ( $\mathrm{g} / 100 \mathrm{~g}$ of total FA) ${ }^{1}$

\begin{tabular}{|c|c|c|c|c|c|c|c|c|c|c|}
\hline \multirow[b]{2}{*}{ Isomer } & \multicolumn{3}{|c|}{ Management system² } & \multicolumn{4}{|c|}{ Lipid supplement $^{3}$} & \multicolumn{3}{|c|}{ Effect, ${ }^{4} P$-value } \\
\hline & PAS & $\mathrm{CON}$ & SEM & $\mathrm{CO}$ & $\mathrm{FO}$ & MA & SEM & MS & $\mathrm{LS}$ & $\mathrm{MS} \times \mathrm{LS}$ \\
\hline \multicolumn{11}{|l|}{ trans 18:1 isomer } \\
\hline trans-4 & 0.03 & 0.04 & $<0.01$ & 0.03 & 0.03 & 0.04 & $<0.01$ & 0.49 & 0.59 & 0.46 \\
\hline trans -5 & 0.03 & 0.04 & $<0.01$ & 0.03 & 0.03 & 0.04 & $<0.01$ & 0.16 & 0.52 & 0.86 \\
\hline trans- 6, trans -8 & 0.37 & 0.35 & 0.02 & $0.27^{\mathrm{a}}$ & $0.37^{\mathrm{b}}$ & $0.45^{\mathrm{c}}$ & 0.02 & 0.44 & $<0.01$ & 0.56 \\
\hline trans -9 & 0.33 & 0.32 & 0.01 & $0.23^{\mathrm{a}}$ & $0.34^{\mathrm{b}}$ & $0.42^{\mathrm{c}}$ & 0.01 & 0.61 & $<0.01$ & 0.54 \\
\hline trans -10 & 0.54 & 0.50 & 0.03 & $0.36^{\mathrm{a}}$ & $0.53^{\mathrm{b}}$ & $0.65^{\mathrm{c}}$ & 0.03 & 0.49 & $<0.01$ & 0.92 \\
\hline trans $-11^{5}$ & 2.79 & 1.29 & 0.09 & 1.61 & 1.94 & 2.40 & 0.11 & 0.01 & $<0.01$ & 0.03 \\
\hline trans-12 & 0.38 & 0.45 & 0.04 & $0.25^{\mathrm{a}}$ & $0.45^{\mathrm{b}}$ & $0.54^{\mathrm{c}}$ & 0.02 & 0.11 & $<0.01$ & 0.72 \\
\hline trans-13/trans-14 & 0.72 & 0.80 & 0.04 & $0.46^{\mathrm{a}}$ & $0.83^{\mathrm{b}}$ & $0.99^{\mathrm{c}}$ & 0.04 & 0.19 & $<0.01$ & 0.28 \\
\hline trans -15 & 0.28 & 0.28 & 0.01 & $0.17^{\mathrm{a}}$ & $0.31^{\mathrm{b}}$ & $0.37^{\mathrm{c}}$ & 0.01 & 0.93 & $<0.01$ & 0.08 \\
\hline trans -16 & 0.42 & 0.37 & 0.04 & $0.26^{\mathrm{a}}$ & $0.40^{\mathrm{b}}$ & $0.47^{\mathrm{c}}$ & 0.01 & 0.06 & $<0.01$ & 0.08 \\
\hline \multicolumn{11}{|c|}{ Conjugated 18:2 isomer } \\
\hline cis- 9, trans $-11^{6}$ & 1.02 & 0.51 & 0.03 & 0.62 & 0.74 & 0.87 & 0.13 & 0.01 & $<0.01$ & 0.04 \\
\hline trans-9,cis-11 & 0.03 & 0.03 & 0.01 & $0.02^{\mathrm{a}}$ & $0.03^{\mathrm{b}}$ & $0.03^{\mathrm{b}}$ & $<0.01$ & 0.55 & 0.03 & 0.51 \\
\hline cis- 11, trans -13 & 0.05 & 0.04 & $<0.01$ & $0.03^{\mathrm{a}}$ & $0.06^{\mathrm{b}}$ & $0.05^{\mathrm{b}}$ & 0.01 & 0.58 & $<0.01$ & 0.16 \\
\hline trans -10, cis- 12 & 0.01 & 0.01 & $<0.01$ & 0.01 & 0.01 & 0.01 & $<0.01$ & 0.98 & 0.57 & 0.09 \\
\hline trans -11, cis $-13^{7}$ & 0.06 & 0.04 & $<0.01$ & $0.04^{\mathrm{a}}$ & $0.05^{\mathrm{b}}$ & $0.05^{\mathrm{b}}$ & $<0.01$ & 0.03 & 0.02 & 0.69 \\
\hline trans-11,trans-13 & 0.02 & 0.01 & 0.01 & 0.01 & 0.02 & 0.02 & 0.01 & 0.12 & 0.16 & 0.68 \\
\hline Other trans, trans $^{8}$ & 0.14 & 0.12 & 0.01 & $0.11^{\mathrm{a}}$ & $0.14^{\mathrm{b}}$ & $0.15^{\mathrm{b}}$ & 0.01 & 0.35 & 0.01 & 0.73 \\
\hline
\end{tabular}

\footnotetext{
${ }^{a-c}$ Values within lipid supplement and in the same row not sharing a common superscript are significantly different $(P \leq 0.05)$.

${ }^{1}$ Least squares means from 90 DIM.

${ }^{2} \mathrm{PAS}=$ pasture system; CON $=$ confinement system.

${ }^{3}$ Supplementation with rumen-protected fish oil (FO), rumen-protected microalgae (MA), or control (CO; no marine oil supplement).

${ }^{4}$ Effects of management system (MS), lipid supplement (LS), and their interaction (MS $\times$ LS).

${ }^{5}$ Vaccenic acid.

${ }^{6}$ Rumenic acid; co-elutes with trans-7,cis-9 and trans-8,cis-10 18:2.

${ }^{7}$ Co-elutes with cis-9, cis-11 18:2.

${ }^{8}$ trans- - ,trans- $9+$ trans- 8, trans- $10+$ trans- 9, trans- $11+$ trans- 10, trans-12 18:2.
} 
Table 6. The trans 18:1 isomer distribution (\% of total trans 18:1) of milk fat from Holstein cows on pasture or in confinement receiving no marine oil supplement (control; CO), rumen-protected fish oil (FO), or rumen-protected microalgae (MA) ${ }^{1}$

\begin{tabular}{|c|c|c|c|c|c|c|c|c|c|c|}
\hline \multirow[b]{2}{*}{ trans $18: 1$ isomer } & \multicolumn{3}{|c|}{ Pasture } & \multicolumn{3}{|c|}{ Confinement } & \multirow[b]{2}{*}{ SEM } & \multicolumn{3}{|c|}{ Effect, ${ }^{2} P$-value } \\
\hline & $\mathrm{CO}$ & FO & MA & $\mathrm{CO}$ & FO & MA & & MS & LS & $\mathrm{MS} \times \mathrm{LS}$ \\
\hline trans-5 & 0.56 & 0.47 & 0.42 & 1.34 & 0.88 & 0.91 & 0.14 & 0.06 & 0.07 & 0.34 \\
\hline trans-6,trans-8 & 7.09 & 6.61 & 6.06 & 9.03 & 7.59 & 7.63 & 0.36 & 0.08 & $<0.01$ & 0.09 \\
\hline trans -9 & 5.89 & 6.05 & 5.62 & 7.56 & 7.09 & 7.13 & 0.44 & 0.13 & 0.33 & 0.35 \\
\hline trans-10 & 9.81 & 9.63 & 10.63 & 11.10 & 11.42 & 11.33 & 0.93 & 0.38 & 0.64 & 0.66 \\
\hline trans-13/trans-14 & $8.74^{\mathrm{a}}$ & $13.07^{\mathrm{b}}$ & $14.08^{\mathrm{b}}$ & $17.74^{\mathrm{cd}}$ & $19.53^{\mathrm{c}}$ & $17.07^{\mathrm{d}}$ & 0.51 & $<0.01$ & $<0.01$ & $<0.01$ \\
\hline trans-15 & $3.68^{\mathrm{a}}$ & $5.13^{\mathrm{b}}$ & $5.22^{\mathrm{b}}$ & $6.38^{\mathrm{c}}$ & $7.07^{\mathrm{d}}$ & $6.08^{\mathrm{c}}$ & 0.22 & $<0.01$ & $<0.01$ & $<0.01$ \\
\hline trans-16 & $4.51^{\mathrm{a}}$ & $6.21^{\mathrm{b}}$ & $6.16^{\mathrm{b}}$ & $7.24^{\mathrm{c}}$ & $7.46^{\mathrm{c}}$ & $6.26^{\mathrm{d}}$ & 0.22 & 0.02 & $<0.01$ & $<0.01$ \\
\hline
\end{tabular}

$\overline{\mathrm{a}-\mathrm{d}}$ Values within a row not sharing a common superscript are significantly different $(P \leq 0.05)$. Letter grouping was performed only when MS $\times$ LS was significant $(P \leq 0.05)$ to show differences among all 6 treatment combinations.

${ }^{1}$ Least squares means from 90 DIM.

${ }^{2}$ Effects of management system (MS), lipid supplement (LS), and their interaction $(\mathrm{MS} \times \mathrm{LS})$.

confinement compared with pasture, and tended $(P \leq$ $0.07)$ to be reduced by lipid supplementation.

\section{DISCUSSION}

\section{Animal Performance}

The lower yields of milk, milk fat, protein, and lactose observed in the pasture group compared with those in the confinement group are related to the lower estimated DMI in grazing cows (Table 3$)$. The tendency $(P$ $=0.10$ ) of reduced BCS in grazing cows compared with confined cows is likely due to the greater mobilization of body reserves (Agenäs et al., 2002; Vahmani et al., 2011).

Despite the reduced milk fat percentage in MA-fed cows compared with those fed FO or the control, milk fat yield was not affected by LS $(P=0.22$; Table 3$)$. Feeding FO or MA to dairy cows has been associated with either reduction (Cant et al., 1997; Franklin et al., 1999; Ahnadi et al., 2002; Boeckaert, et al., 2008) or no change (Allred et al. 2006; Stamey et al., 2012) in milk fat yield. The discrepancy could be related to differences in the amount of LS fed, rumen protection method, length of feeding period, and composition of basal diets.

\section{Milk FA Composition}

Compared with confinement, grazing increased milk fat content of several beneficial UFA (ALA, OA, VA, and RA) at the expense of 12:0 to 16:0. These results are consistent with previous studies showing that pasture-based milk has a significantly more healthful FA composition than that of milk from confined cows fed conserved forages and more concentrate (Dewhurst et al., 2006; Kalač and Samková, 2010). This phenomenon has been related mainly to the higher intake of PUFA in grazing cows, particularly ALA, the predominant FA (50-75\% of total FA) in fresh forage (Chilliard et al., 2007). The majority of this FA is lost by ensiling and storing (Dewhurst et al., 2006; Kalač and Samková, 2010). Consistent with these studies, ALA was the major FA in pasture, whereas in TMR, linoleic acid (LeA; 18:2 n-6) was the predominant FA, which originated mainly from concentrate (Table 1). The lower milk fat content of 12:0 to 16:0 in grazing cows was likely due to reduced mammary de novo FA synthesis (Couvreur et al., 2007). The majority of 12:0 and 14:0, and about $50 \%$ of $16: 0$ are synthesized de novo in the mammary gland, a process that is inhibited directly by ALA or indirectly via its RBH intermediates (Chilliard et al., 2007). Consequently, we observed higher milk concentrations of ALA, trans 18:1 and CLA in grazing cows compared with confined cows (Table 4). Similarly, the lower milk fat content of 16:0 in cows fed FO or MA could be due to the inhibition of mammary de novo FA synthesis (Ahnadi et al., 2002). Fish oil and MA provided 25 and $51 \mathrm{~g}$ of 16:0 per day, respectively (Table 1), an insufficient amount, apparently, to compensate for reduced mammary synthesis of 16:0. The higher milk fat content of OA of grazing cows relates to the increased mammary supply of 18:0 providing more substrate for mammary $\Delta^{9}$-desaturase. The higher intake of ALA by grazing cows can increase the ruminal outflow of its RBH end product 18:0, as well as numerous RBH intermediates (Chilliard et al., 2007). Greater mobilization of body reserves in grazing cows compared with confined cows could also have contributed to higher mammary supply of 18:0 (Agenäs et al., 2002). 
Mobilization of body fat also releases 16:0 but as the milk fat content of this FA was $17 \%$ lower $(P=0.01$; Table 4) in grazing cows, the source of increased levels of 18:0 in milk of grazing cows was likely not adipose.

The relatively lower milk content of ALA of grazing cows in our study $(0.57 \%$ vs. $0.9 \pm 0.2 \%$ in the review by Vahmani et al., 2013) was likely due to a lower concentration of ALA in our pasture (48\% of total FA; Table 1) relative to levels observed in previous studies (50-75\% of total FA; Chilliard et al., 2007). The concentration of ALA in pasture can be affected by several factors such as season, species composition, and stage of plant growth (Dewhurst et al., 2006). Although a tendency $(P=0.09)$ existed for higher milk fat content of n-3 PUFA, we did not observe any improvement in the n6:n3 ratio of milk from grazing cows, which coincided with a concurrent increase in the content of n- 6 PUFA, particularly CLA, in milk from grazing cows (Table 4).

The estimated transfer efficiency of supplemental DHA into milk in our study is close to the average value $(4.1 \%)$ for unprotected marine oils (Chilliard et al., 2001). However, high variation in transfer efficiency for both unprotected and protected FO (unprotected: $1.6-16.2 \%$ vs. protected: $5.1-18.0 \%$ ) and MA (unprotected: $1.60-8.40 \%$ vs. protected: $2.0-16.7 \%$ ) was found in other studies (Cant et al., 1997; Franklin et al., 1999; Kitessa et al., 2004; Castañeda-Gutiérrez et al., 2007; Osborne et al., 2008; Stamey et al., 2012). This variation can be explained by differences in the amount of supplemental lipid fed and its content of DHA, efficacy of ruminal protection, duration of feeding trials, and basal diet composition (Chilliard et al., 2001; Chilliard et al., 2007). The low transfer efficiency of EPA and DHA into milk has been attributed to $\mathrm{RBH}$, as well as preferential incorporation into the blood phospholipid and cholesterol ester fractions, which are less efficiently used by the mammary compared with triacylglycerol and NEFA (Chilliard et al., 2001).

Despite the relatively low transfer efficiency, feeding FO or MA increased the milk fat content of n-3 LC-PUFA 1.5 fold compared with the control (Table 4). Using the average consumption $(\sim 700 \mathrm{~g} / \mathrm{d})$ of milk equivalent $(\sim 3.6 \%$ milk fat basis) in the United States and Canada (Informa Economics Inc., 2010), our enriched milk would provide approximately $59 \mathrm{mg} / \mathrm{d}$ more n-3 LC-PUFA than the control milk. The intake of n-3 LC-PUFA in the United States and Canada is estimated to be 100 to $200 \mathrm{mg} / \mathrm{d}$ (Kris-Etherton et al., 2000; Denomme et al., 2005), which is considerably lower than the recommended adequate intake of 650 mg/d (Simopoulos et al., 1999).

The higher milk fat concentration of trans 18:1 and CLA (Table 4) in grazing cows compared with confined cows was related mainly to increased concentrations of VA and RA, respectively (Table 5). Vaccenic acid is an intermediate in the RBH of OA, LeA, and ALA, and is the predominant $\mathrm{RBH}$ intermediate found in ruminant milk and meat (Shingfield et al., 2008). Rumenic acid is the predominant CLA isomer found in ruminant fat and can be produced either in the rumen as a $\mathrm{RBH}$ intermediate, or via mammary $\Delta^{9}$-desaturase action on VA (Shingfield et al., 2008; Shingfield et al., 2010). Mammary desaturase activity accounts for 64 to $97 \%$ of milk RA (Shingfield et al., 2010); therefore, dietary treatments that increase ruminal production of VA (e.g., feeding pasture) will increase milk fat content of both VA and RA. Besides higher intake of ALA, a precursor to VA, ruminal conditions in grazing cows (e.g., ruminal microbiome, $\mathrm{pH}$, rumen fill, and digesta kinetics) could also contribute to higher ruminal production/outflow of VA (Mohammed et al., 2009). Although the exact role of many of these factors remains to be elucidated, the higher ruminal passage rate and lower ruminal $\mathrm{pH}$ in grazing cows compared with TMR-fed cows (Schroeder et al., 2004) could lead to a greater outflow of RBH intermediates such as VA from the rumen. Besides RA, the predominate CLA isomer, we observed a higher milk fat concentration of trans-11,cis-13 CLA in grazing cows compared with confined cows (Table 5). This CLA isomer is produced in the rumen as an intermediate in the RBH of ALA and is known as the second major CLA isomer (after RA) found in milk produced on alpine pastures (Chilliard et al., 2007).

Supplementation of dairy cows with marine oils stimulates ruminal production of VA, increasing milk fat content of VA, as well as its $\Delta^{9}$-desaturation product, RA (Chilliard et al., 2007). We observed significant improvements in milk fat content of these 2 FA only when FO or MA were fed to confined cows, but not when these supplements were fed to grazing cows (Figure 1). We found that supplementation of grazing cows with FO or MA increased the relative concentration $(\%$ of total trans 18:1) of several other trans 18:1 isomers (trans-12 to trans-16 18:1) at the expense of VA (Table 6 ). In contrast to our results, previous studies consistently reported improvements in milk fat content of VA and RA when grazing cows were supplemented with marine oils (AbuGhazaleh et al., 2007; AbuGhazaleh and Holmes, 2007; Brown et al., 2008). However, in these studies, marine oils were fed along with a source of LeA and ALA (e.g., sunflower oil). In studies (Kitessa et al., 2004; Rego et al., 2005; Glover et al., 2012) in which marine oils were fed alone (with no plant oils) to grazing cows, trans 18:1 and CLA were reported as sums, not as individual isomers. Many factors could be involved in the different responses of confined and graz- 
ing cows in terms of milk VA and RA, to feeding FO or MA in our study. Some of these factors may include differences in intake and type of $\mathrm{RBH}$ substrates (i.e., LeA and ALA), ruminal $\mathrm{pH}$, and ruminal microbiome. The ruminal production of VA may have also reached its maximum in grazing cows; therefore, feeding FO or MA resulted in an increase in the production of alternative $\mathrm{RBH}$ intermediates (e.g., trans-12 to trans- 16 18:1; Table 6).

Besides VA, which is considered beneficial (Shingfield et al., 2008), feeding FO or MA increased milk fat levels of several other trans 18:1 isomers, and the extent of the increase was greater with MA than with FO (Table 5). This phenomenon could be due to the higher proportion (about 2 times) of DHA in MA compared with FO (Table 1). AbuGhazaleh and Jenkins (2004) suggested that compared with EPA, DHA is a stronger inhibitor of $\mathrm{RBH}$, resulting in the accumulation of higher levels of $\mathrm{RBH}$ intermediates (e.g., trans 18:1 isomers) in the rumen. Generally, trans FA have been associated with increased risk of cardiovascular disease by increasing blood low-density lipoprotein (LDL) cholesterol and reducing high-density lipoprotein (HDL) cholesterol (Gebauer et al., 2007). Ruminant foods contribute about $20 \%$ of total trans FA intake of North Americans (Shingfield et al., 2008). The major dietary source of trans FA (i.e., trans 18:1), however, is partially hydrogenated vegetable oil (PHVO; $80 \%$ of total trans FA intake). In contrast to PHVO trans FA, no evidence exists that ruminant trans FA are associated with cardiovascular disease risk (Shingfield et al., 2008) due to the difference in profile of trans 18:1 between PHVO and ruminant fat (Gebauer et al., 2007). The predominant trans 18:1 in ruminant fat is VA (40-70\% of total trans 18:1), whereas trans-6-8, trans-9, and trans-10 18:1 are predominant in PHVO, comprising more than $60 \%$ of total trans 18:1 (Shingfield et al., 2008). The health effects of individual trans 18:1 isomers (other than VA) are negative or unknown. Improving the milk FA profile should target those FA considered beneficial to human health while identifying and lowering those that are potentially harmful.

\section{CONCLUSIONS}

Our results confirm previous research showing milk produced in pasture systems has a more healthful FA profile than that of confinement systems. Compared with confined cows, grazing cows produced milk with a higher content of beneficial UFA (OA, VA, RA and ALA) and lower content of 12:0-16:0. The use of pastures in dairy systems in temperate North America could improve the image of milk fat which is currently associated only with high content of SFA and less of beneficial UFA. In addition to the beneficial effects of pasture on milk FA composition, feeding FO or MA could also enhance the milk fat concentration of n-3 LC-PUFA and reduce the content of 16:0 in both pasture and confinement systems without compromising milk fat yield. However, feeding FO or MA interacted with MS in terms of milk fat content of VA and RA. In contrast to confined cows, marine oil supplements did not improve milk fat content of VA and RA in grazing cows. This could be due to differences between grazing and confinement in terms of intake of RBH substrates and ruminal environment. Supplementing dairy cow diets with FO or MA resulted in increased milk fat levels of several trans 18:1 isomers other than VA, the health effects of which are unknown. Thus, more studies are needed on human health consequences of modifying the UFA composition of milk fat by feeding oils to dairy cows.

\section{ACKNOWLEDGMENTS}

The Atlantic Innovation Fund (AIF), Atlantic Canada Opportunities Agency (ACOA; Moncton, New Brunswick, Canada) and the Dairy Farmers of Nova Scotia (Lower Truro, NS, Canada) provided the funding for this study. We acknowledge the technical assistance of Tennille Crossman (Department of Plant and Animal Sciences, Dalhousie University, Truro, NS, Canada) with FA analysis and Ken McRae (independent research professional, Kentville, NS, Canada) for assistance with experimental design and statistical analysis.

\section{REFERENCES}

AbuGhazaleh, A. A., D. O. Felton, and S. A. Ibrahim. 2007. Milk conjugated linoleic acid response to fish oil and sunflower oil supplementation to dairy cows managed under two feeding systems. J. Dairy Sci. 90:4763-4769.

AbuGhazaleh, A. A., and L. D. Holmes. 2007. Diet supplementation with fish oil and sunflower oil to increase conjugated linoleic acid levels in milk fat of partially grazing dairy cows. J. Dairy Sci. 90:2897-2904.

AbuGhazaleh, A. A., and T. C. Jenkins. 2004. Disappearance of docosahexaenoic and eicosapentaenoic acids from cultures of mixed ruminal microorganisms. J. Dairy Sci. 87:645-651.

AbuGhazaleh, A. A., R. B. Potu, and S. Ibrahim. 2009. Short communication: The effect of substituting fish oil in dairy cow diets with docosahexaenoic acid-micro algae on milk composition and fatty acids profile. J. Dairy Sci. 92:6156-6159.

Agenäs, S., K. Holtenius, M. Griinari, and E. Burstedt. 2002. Effects of turnout to pasture and dietary fat supplementation on milk fat composition and conjugated linoleic acid in dairy cows. Acta Agric. Scand. A Anim. Sci. 52:25-33.

Ahnadi, C. E., N. Beswick, L. Delbecchi, J. J. Kennelly, and P. Lacasse. 2002. Addition of fish oil to diets for dairy cows. II. Effects on milk fat and gene expression of mammary lipogenic enzymes. J. Dairy Res. 69:521-531.

Allred, S. L., T. R. Dhiman, C. P. Brennand, R. C. Khanal, D. J. McMahon, and N. D. Luchini. 2006. Milk and cheese from cows 
fed calcium salts of palm and fish oil alone or in combination with soybean products. J. Dairy Sci. 89:234-248.

Arsenault, N., P. Tyedmers, and A. Fredeen. 2009. Comparing the environmental impacts of pasture-based and confinement-based dairy systems in Nova Scotia (Canada) using life cycle assessment. Int. J. Agric. Sustain. 7:19-41.

Boeckaert, C., B. Vlaeminck, J. Dijkstra, A. Issa-Zacharia, T. Van Nespen, W. Van Straalen, and V. Fievez. 2008. Effect of dietary starch or micro algae supplementation on rumen fermentation and milk fatty acid composition of dairy cows. J. Dairy Sci. 91:47144727.

Brown, W., A. A. AbuGhazaleh, and S. A. Ibrahim. 2008. Milk conjugated linoleic acid response to fish oil and linseed oil supplementation of grazing dairy cows. Asian-australas. J. Anim. Sci. 21:663-670.

Budge, S. M., S. J. Iverson, and H. N. Koopman. 2006. Studying trophic ecology in marine ecosystems using fatty acids: A primer on analysis and interpretation. Mar. Mamm. Sci. 22:759-801.

Cant, J. P., A. H. Fredeen, T. MacIntyre, J. Gunn, and N. Crowe. 1997. Effect of fish oil and monensin on milk composition in dairy cows. Can. J. Anim. Sci. 77:125-131.

Castañeda-Gutiérrez, E., M. J. de Veth, A. L. Lock, D. A. Dwyer, K D. Murphy, and D. E. Bauman. 2007. Effect of supplementation with calcium salts of fish oil on n-3 fatty acids in milk fat. J. Dairy Sci. 90:4149-4156

Chilliard, Y., A. Ferlay, and M. Doreau. 2001. Effect of different types of forages, animal fat or marine oils in cow's diet on milk fat secretion and composition, especially conjugated linoleic acid (CLA) and polyunsaturated fatty acids. Livest. Prod. Sci. 70:31-48.

Chilliard, Y., F. Glasser, A. Ferlay, L. Bernard, J. Rouel, and M Doreau. 2007. Diet, rumen biohydrogenation and nutritional quality of cow and goat milk fat. Eur. J. Lipid Sci. Technol. 109:828 855 .

Cosgrove, D. R., and D. P. Cooper. 2007. Predicting dry matter intake and manure production of grazing dairy cows. Pages $253-255$ in Proc. Wisconsin Fertilizer, Aglime and Pest Management Conference, Vol. 46. Univ. Wisconsin, Madison.

Couvreur, S., C. Hurtaud, P. G. Marnet, P. Faverdin, and J. L. Peyraud. 2007. Composition of milk fat from cows selected for milk fat globule size and offered either fresh pasture or a corn silage-based diet. J. Dairy Sci. 90:392-403.

Cruz-Hernandez, C., J. K. G. Kramer, J. Kraft, V. Santercole, M. Or-Rashid, Z. Deng, M. E. R. Dugan, P. Delmonte, and M. P. Yurawecz. 2006. Systematic analysis of trans and conjugated linoleic acids in the milk and meat of ruminants. Pages 45-93 in Advances in Conjugated Linoleic Acid Research. Vol. 3. Am. Oil Chem. Soc., Champaign, IL.

Denomme, J., K. D. Stark, and B. J. Holub. 2005. Directly quantitated dietary (n-3) fatty acid intakes of pregnant Canadian women are lower than current dietary recommendations. J. Nutr. 135:206211.

Dewhurst, R. J., K. J. Shingfield, M. R. F. Lee, and N. D. Scollan. 2006. Increasing the concentrations of beneficial polyunsaturated fatty acids in milk produced by dairy cows in high-forage systems. Anim. Feed Sci. Technol. 131:168-206.

Folch, J., M. Lees, and G. H. S. Stanley. 1957. A simple method for the isolation and purification of total lipides from animal tissues. J. Biol. Chem. 226:497-509.

Franklin, S. T., K. R. Martin, R. J. Baer, D. J. Schingoethe, and A. R. Hippen. 1999. Dietary marine algae (Schizochytrium sp.) increases concentrations of conjugated linoleic, docosahexaenoic and trans vaccenic acids in milk of dairy cows. J. Nutr. 129:2048-2054.

Gebauer, S. K., T. L. Psota, and P. M. Kris-Etherton. 2007. The diversity of health effects of individual trans fatty acid isomers. Lipids 42:787-799.

Glasser, F., M. Doreau, A. Ferlay, and Y. Chilliard. 2007. Technical note: Estimation of milk fatty acid yield from milk fat data. J. Dairy Sci. 90:2302-2304.

Glover, K. E., S. Budge, M. Rose, H. P. V. Rupasinghe, L. MacLaren, J. Green-Johnson, and A. H. Fredeen. 2012. Effect of feeding fresh forage and marine algae on the fatty acid composition and oxidation of milk and butter. J. Dairy Sci. 95:2797-2809.

Informa Economics Inc. 2010. An international comparison of milk supply control programs and their impacts. Prepared for International Dairy Foods Association. Informa Economics Inc., Eagan, MN.

Kalač, P., and E. Samková. 2010. The effects of feeding various forages on fatty acid composition of bovine milk fat: A review. Czech J. Anim. Sci. 55:521-537.

Kitessa, S. M., S. K. Gulati, G. C. Simos, J. R. Ashes, T. W. Scott, E. Fleck, and P. C. Wynn. 2004. Supplementation of grazing dairy cows with rumen-protected tuna oil enriches milk fat with n-3 fatty acids without affecting milk production or sensory characteristics. Br. J. Nutr. 91:271-278.

Kramer, J. K., M. Hernandez, C. Cruz-Hernandez, J. Kraft, and M. E. Dugan. 2008. Combining results of two GC separations partly achieves determination of all cis and trans 16:1, 18:1, 18:2 and 18:3 except CLA isomers of milk fat as demonstrated using Ag-ion SPE fractionation. Lipids 43:259-273.

Kris-Etherton, P. M., D. S. Taylor, S. Yu-Poth, P. Huth, K. Moriarty, V. Fishell, R. L. Hargrove, G. Zhao, and T. D. Etherton. 2000 Polyunsaturated fatty acids in the food chain in the United States. Am. J. Clin. Nutr. 71:179S-188S.

Mohammed, R., C. S. Stanton, J. J. Kennelly, J. K. Kramer, J. F. Mee, D. R. Glimm, M. O'Donovan, and J. J. Murphy. 2009. Grazing cows are more efficient than zero-grazed and grass silage-fed cows in milk rumenic acid production. J. Dairy Sci. 92:3874-3893.

Osborne, V. R., S. Radhakrishnan, N. E. Odongo, A. R. Hill, and B. W. McBride. 2008. Effects of supplementing fish oil in the drinking water of dairy cows on production performance and milk fatty acid composition. J. Anim. Sci. 86:720-729.

Rego, O. A., H. J. D. Rosa, P. Portugal, R. Cordeiro, A. E. S. Borba, C. M. Vouzela, and R. J. B. Bessa. 2005. Influence of dietary fish oil on conjugated linoleic acid, omega-3 and other fatty acids in milk fat from grazing dairy cows. Livest. Prod. Sci. 95:27-33.

Rust, J. W., C. C. Sheaffer, V. R. Eidman, R. D. Moon, and R. D. Mathison. 1995. Intensive rotational grazing for dairy cattle feeding. Am. J. Altern. Agric. 10:147-151.

Schroeder, G., G. Gagliostro, F. Bargo, J. Delahoy, and L. Muller. 2004. Effects of fat supplementation on milk production and composition by dairy cows on pasture: A review. Livest. Prod. Sci. $86: 1-18$.

Shingfield, K. J., L. Bernard, C. Leroux, and Y. Chilliard. 2010. Role of trans fatty acids in the nutritional regulation of mammary lipogenesis in ruminants. Animal 4:1140-1166.

Shingfield, K. J., Y. Chilliard, V. Toivonen, P. Kairenius, and D. I. Givens. 2008. Trans fatty acids and bioactive lipids in ruminant milk. Adv. Exp. Med. Biol. 606:3-65.

Sijtsma, L., and M. E. de Swaaf. 2004. Biotechnological production and applications of the omega-3 polyunsaturated fatty acid docosahexaenoic acid. Appl. Microbiol. Biotechnol. 64:146-153.

Simopoulos, A. P., A. Leaf, and N. Salem Jr.. 1999. Workshop on the essentiality of and recommended dietary intakes for omega- 6 and omega-3 fatty acids. J. Am. Coll. Nutr. 18:487-489.

Stamey, J. A., D. M. Shepherd, M. J. de Veth, and B. A. Corl. 2012. Use of algae or algal oil rich in n-3 fatty acids as a feed supplement for dairy cattle. J. Dairy Sci. 95:5269-5275.

Vahmani, P., A. Fredeen, and K. Glover. 2013. Dairy system impacts on milk fat composition related to human health. Pages 47-60 in Milk Fat: Composition, Nutritional Value and Health Implications. Nova Science Publishers Inc., Hauppauge, NY.

Vahmani, P., K. Glover, L. A. MacLaren, J. Green-Johnson, and A. Fredeen. 2011. Effects of marine oil supplements on bioenergetic and milk production parameters in grazing or confined cows 90 days post-calving. Can. J. Anim. Sci. 91:497. (Abstr.)

Wildman, E. E., G. M. Jones, P. E. Wagner, R. L. Boman, H. R. Troutt Jr., and T. N. Lesch. 1982. A dairy cow body condition scoring system and its relationship to selected production characteristics. J. Dairy Sci. 65:495-501. 